\title{
Hepatitis B is Increasing in Ethiopian Blood Banks: A Mini Review
}

\author{
Hylemariam Mihiretie Mengist* \\ Department of Medical Laboratory Sciences, Wollega University, Ethiopia
}

Submission: July 15, 2017; Published: July 27, 2017

"Corresponding author: Hylemariam Mihiretie Mengist, Department of Medical Laboratory Sciences, Wollega University, Ethiopia, Email: hylemariam@gmail.com

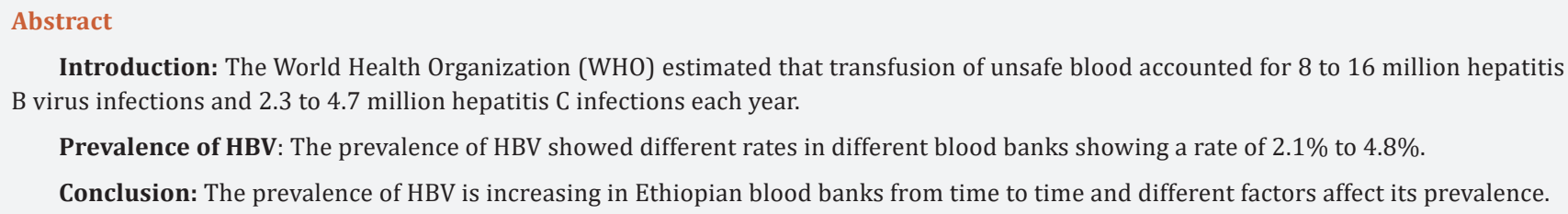

\section{Introduction}

The World Health Organization (WHO) estimated that transfusion of unsafe blood accounted for 8 to 16 million hepatitis $\mathrm{B}$ virus infections and 2.3 to 4.7 million hepatitis $\mathrm{C}$ infections each year [1]. It is estimated that in sub-Saharan Africa, more than 45,000 hepatitis B viruses or hepatitis C virus infections are transmitted through contaminated transfusions annually [2].

Although infectious diseases have many transmission routes, blood donation can be significant avenues for transmission of these diseases to healthy individuals. Most donated blood in Ethiopia is not screened adequately for TTIs due to the lack of a consistent supply of screening reagents and materials. This is a major challenge to the transfusion services in Ethiopia and throughout the underdeveloped world. As a result, use of unscreened blood puts the patient at risk of acquiring many TTIs. Such patients can become potential sources of infection to the community. Consequently, disease burden can impact the entire country and can trigger additional costs for diagnosis and treatment of diseases [3-5].

\section{Prevalence and Associated Factors of Hepatitis B virus}

A study reported that the prevalence of HBV in Ethiopian blood banks from 2009-2013 was 4.8\% [6]. The prevalence rate of Hepatitis B Virus was $2.1 \%$. Sex and age had statistically significant association with Hepatitis B virus infections where females were less likely to be infected. As age increases above 20 years, the risk of infection with Hepatitis B Virus increases [7].
Prevalence of HBV was $4.7 \%$ in Arbaminch Blood Bank. From 17 participants tested positive for HBV, 8 (47\%) were males. The test positivity among male was $8 / 197$ (4.1\%) while among females was $9 / 162(5.6 \%)$ and more than three forth participants tested positive were age less than 25. Participants earning 581-1,300 birr were $32.2 \%$ less likely to have infection than participants earning below 580 birr per month. Volunteer donors who exposed to unsafe therapeutic drug injection were 11 times increased risk of HBV infection [8]. Among 384 blood donors, $16(4.2 \%)$ were positive for HBV in Hawassa Blood Bank [9]. A systematic review and meta-analysis conducted in 2016 showed a pooled HBV prevalence of $8.4 \%$ in blood donors [10] (Table 1).

Table 1: Prevalence associated factors of HBV in Ethiopian Blood banks.

\begin{tabular}{|c|c|c|}
\hline Blood Bank & Study Period & HBV Positivity \\
\hline Jimma University & 2010 & $2.1 \%$ \\
\hline Yirgalem & $2009-2013$ & $4.8 \%$ \\
\hline Dire Dawa & $2009-2014$ & $4.2 \%$ \\
\hline Arba Minch & 2015 & $4.7 \%$ \\
\hline Meta-analysis & 2016 & $8.4 \%$ \\
\hline
\end{tabular}

\section{Conclusion}

HBV showed increasing prevalence in Ethiopian blood banks. Sex and age significantly affect the prevalence of HBV in 
different study areas. Blood banks should use reliable diagnosis techniques to promote safe blood donation.

\section{References}

1. World Health Organization (WHO) (2001) Blood Transfusion Service: Global database on blood safety from 1998-1991. WHO/BTS, Summary report, Geneva, Switzerland.

2. Apata IW, Averhoff F, Pitman J, Bjork A, Yu J, et al. (2014) Progress toward Prevention of Transfusion-Transmitted Hepatitis B and Hepatitis C Infection-Sub-Saharan Africa, 2000-2011. MMWR Morb Mortal Wkly Rep 63(29): 613-641.

3. Buseri FI, Muhibi MA, Jeremiah ZA (2009) Sero-epidemiology of transfusion transmissible infectious diseases among blood donors in Osogbo, southwest Nigeria. Blood Transfus 7(4): 293-299.

4. National Blood Transfusion Services Strategy (2005) Federal Democratic Republic of Ethiopia, Ministry of Health. Addis Ababa, Ethiopia.

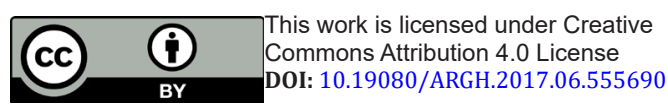

5. Holmberg J (2006) Activities Relating to Global Blood Safety at the Department of Health and Human Services. pp. 1-5.

6. Birhaneselassie M (2016) Prevalence of Transfusion-Transmissible Infections in Donors to an Ethiopian Blood Bank Between 2009 and 2013 and Donation Factors That Would Improve the Safety of the Blood Supply in Underdeveloped Countries. Lab Med 47(2): 134-139.

7. Yami A, Alemseged F, Hassen A (2011) Hepatitis B and C Viruses Infections and their Association with Human Immunodeficiency Virus: A cross-sectional study among blood donors in Ethiopia. Ethiop J Health Sci 21(1): 67-75.

8. Adato A (2016) Prevalence and Associated Risk Factors of Hepatitis B and Hepatitis C Virus Among Volunteer Blood Donors in Arbaminch Blood Bank. Journal of Medical laboratory and diagnosis 7(4): 2027.

9. Bonja F, Hussein M, Alemu J, Gemechu D, Birhaneselassie M (2017) The prevalence of transfusion transmitted infections: A focus on hepatitis B virus among blood donors at Hawassa blood bank center, Southern Ethiopia. Int J Blood Transfus Immunohematol 7: 7-14.

\section{Your next submission with JuniperPublishers will reach you the below assets}

- Quality Editorial service

- Swift Peer Review

- Reprints availability

- E-prints Service

- Manuscript Podcast for convenient understanding

- Global attainment for your research

- Manuscript accessibility in different formats ( Pdf, E-pub, Full Text, audio)

- Unceasing customer service

Track the below URL for one-step submission https://juniperpublishers.com/online-submission.php 